\title{
Promoting Romanian Music Abroad: The Rumanian Review (1946-1956)
}

\section{JOEL CROTTY}

This essay investigates the promotion of Romanian art music through a selection of articles published in the Rumanian Review between 1946 and 1955, from a time when the nation was on the cusp of the communist takeover and through the early stages of consolidation of the totalitarian regime. ${ }^{1}$ These articles reflect the Party's requirement that the journal should demonstrate Romania's loyalty to the emerging socialist system, and publicise that, in reorganizing its cultural life, the Party had not necessarily abandoned Romania's cultural traditions. Discussion examines what these documents can tell the historian about this turbulent time in relation to the use of music as a tool of governance, how the authors shaped these texts in relation to the prevailing, and sometimes shifting, ideology, and what can be inferred about both supported and marginalized composers in this period.

The Rumanian Review was a monthly literary magazine targeting the surviving intelligentsia within the country and an interested intellectual readership beyond its borders. Published in Bucharest in English, French, and German, as well as Romanian, it aimed to cover "Rumania's political, social, economic, literary, artistic, and scientific life" ${ }^{2}$ in order to demonstrate that the country maintained a flourishing scholastic community. Educated Romanians saw their Latin-based culture as a mirror of that of France and Italy, a connection they valued the more when, in geographic terms, they were almost completely hemmed in by Slavic influences. Whether reflecting Romania's historical cultural alignment to the West before 1948 or the shift towards the Soviet Union thereafter, the Review continued to present Romanian culture in a positive light throughout the decade under discussion. When the communists gained control, the journal became a tool in the hands of the new regime to construct the illusion that "national in form and socialist in content," the catchcry of the period, embodied the most civilizing aspects of European culture. In the articles under consideration, rhetoric and ideological preoccupations often changed to reflect shifts in Party policy, but the overarching rationale of celebrating Romanian musical life remained apparent. Post-takeover reportage consisted mainly of propaganda-driven activity statements. Authors proselytized Soviet-led ideology through musical discussion, in order to reaffirm Romania's loyalty to the system.

In general, the Review took a relatively subtle approach to its promotion of Romanian culture abroad. Romanian newspapers and journals destined for international readers were intended to depict not a scene of Stalinist obscuration and despair, but a nation in constant springtime, culturally open but wary of the

\footnotetext{
${ }^{1}$ Readers will note variant spellings of Rumania/Romania in this article. "U" spelling reflects usage in the sources under discussion; "o" spelling is modern usage, following Ceauşescu's resurrection of the old Latinate form of the country's name in 1964. See Katherine Verdery, National Ideology Under Socialism: Identity and Cultural Politics in Ceausescu's Romania (Berkeley/Los Angeles/Oxford: University of California Press, 1991), 116. I wish to acknowledge the assistance of Dr Kay Dreyfus and Jonathan Dreyfus in the preparation of this article.

2 "La vie politique, sociale, économique, littéraire, artistique, et scientifique de la Roumanie," Revue Roumaine, no. 1 (May 1946): opposite contents page. All quotes from the Rumanian Review are taken from the English-language editions, save no. 1, 1946, which was the French-language version. Linguistic idiosyncrasies are reproduced as they appear in the Review.
} 
imperialist warmongers aligned with the Anglo-Americans. The communists wanted to believe (and some of them probably truly did) that Romania was now the land of the free, where creativity blossomed under the new patronage of the Party. A. Şahighian, editor of the Review during the early takeover period, considered that one of the journal's important roles was to "endeavour to show foreign readers ... in what measure the finest cultural traditions of the past are continued and respected in the RPR." ${ }^{3}$ Marcel Breslasu exemplified these utopian projections in the Review:

Life is throbbing in the thoroughfares of Bucharest, on this day of May, this day of spring. And spring not only because the calendar says so. A grand new spring is filling the souls of our people, renewing and transforming our country. After many centuries of darkness and bondage of body and mind, the sun has begun to rise over these parts which spring had forgotten. ${ }^{4}$

The first issue of the Rumanian Review was published in May 1946, at a time when the country's cultural activities were maintained despite its political turmoil. The communists were in the ascendancy, yet the traditional, western-influenced parties and the monarchy still clung to power, and private property and freedom of expression were still rights. According to Keith Hitchins, this uneasy pluralism allowed the nation's artistic life to preserve "much of its interwar effervescence. Its individualism and aesthetics [still] found expression." By its third issue, the Review had a statement of purpose that read:

The RUMANIAN REVIEW presents, corroborated by documentation, a synthetic survey of Rumanian political, economical and literary life. It serves the cause of mutual good-will and understanding among all peoples, the essential basis of peace, which the world of to-day must establish, lest it perishes. The RUMANIAN REVIEW applies to all its readers for their efficient help in this task, a help that can be rendered by contributing proposals and suggestions. ${ }^{6}$

While standard terms of communist propaganda such as "good-will" (read "friendship") and "peace" might immediately suggest leftist intervention in editorial policy, I would argue that the statement is born of a war-weary nation desperate for intellectual rather than military international engagement. There is further evidence of a pluralist editorial approach in the issues of 1946 with their balanced coverage of American-Romanian cultural relations; Frank Shea, the press attaché at the American Embassy, is interviewed about cultural and scientific links between the two countries, and there are matter-of-fact reports of an exhibition of the American way of life and of the achievements of successful Americans of Romanian origin. $^{7}$

In accordance with the journal's stated aim, these issues also cover the gamut of news about scientific, cultural, political, and economic activities. Music is not neglected, and brief articles and reports appear quite regularly. Table 1 summarises the composers named in a selection of Rumanian Review articles, framed by Andrei Tudor's survey articles of 1946 and 1955. Names such as Alfred Mendelsohn, Leon Klepper, and Hilda Jerea recur, and their compositions are referenced in support of the Party's propaganda (Mendelsohn's Symphony no. 3, "Reconstruction," and Symphony no. 4, "Peace Appeal," receive a number of mentions, as does Jerea's cantata Ode to Stalin's Law). It identifies, through their absence, those composers who failed to meet the new standards, since banishment from the pages of the

\footnotetext{
${ }^{3}$ A. Şahighian “Ten Years...[sic],” Rumanian Review, no. 1 (1956): 11.

${ }^{4}$ Marcel Breslasu, “Art and Culture-Possessions of the Whole People," Rumanian Review, nos. 11-12 (1952): 5.

${ }^{5}$ Keith Hitchins, Rumania 1866-1947 (Oxford: Clarendon Press, 1997), 527.

${ }^{6}$ Rumanian Review, no. 3 (July 1946): opposite contents page.

${ }^{7}$ See "American-Rumanian Cultural Relations: An Interview with Mr. Frank Shea, Press Attaché of the U.S.A. in Rumania," Rumanian Review, no. 3 (July 1946): 97-99 and "Letters and Arts: Brief Notes," Rumanian Review, no. 6 (October 1946): $92-$ 93.
} 
Review bespeaks potent cultural marginalization, particularly for prominent personalities like Mihail Jora and Dimitrie Cuclin.

We can determine something of these composers' relationships with the Romanian regime by the manner in which an émigré such as Marcel Mihalovici was totally ignored after 1947, while Jora, who at the outset had a troubled relationship with the Party, was initially criticised (Socor [5/1949]) or dismissed out of hand (Bălan [8/1951] and Anon. [9/1951]), but ultimately acknowledged after having been rehabilitated for a few years (Tudor [4/1955]). Accordingly, the table may also be viewed as documenting the beginnings of a new national canon with socialist realism as its dominant aesthetic. The regime needed to have a body of preferred scores to differentiate itself from the previous cultural environment, and compositions mentioned in the post-takeover articles laid the foundations for future compositional practice. Canonic construction, however, was always in flux, as it reflected changing ideological trends and the regime's shifting political agendas.

In the Review's very first issue, composer Mihail Andricu offers a condensed survey of Romanian music activity. ${ }^{8}$ Andricu's name recurs positively in all Review articles under consideration, with particular praise directed towards his symphonies. Composers' Union president Matei Socor might have found Andricu's music lacking in socialist intent (5/1949), but his symphonies attracted enough peer praise for the authorities to present him to the increasingly suspicious and Cold-War-informed West as an artist engaged in the respected "European" form. Andricu's symphonies, acceptable to the authorities in Bucharest because of the composer's musical nationalism, continued to link Romania to the West for propaganda purposes, and to the East through the Soviet belief in the symphonic form. Andricu's ambiguous collectivist-individualist streak worked for him until he fell foul of communist authorities in the late 1950s.

Andrei Tudor was a frequent contributor to the Review and a correspondent for a number of other journals and newspapers including Scânteia, an important organ of the Romanian Communist Party. He appears to have been able to accommodate the communist regime; he gained employment at the Conservatorium in Bucharest in 1950 when staff mobility was at its height and those who did not fit the new order were being replaced. Tudor had a special regard for the work of George Enescu, ${ }^{9}$ and his publications go to great lengths to accommodate the Romanian master within the socialist pantheon of composers. In his 1955 survey article, for example, Tudor promoted a tenuous link between the socialist cause and Enescu-who had recently died in exile-with an acknowledgment of the composer's folkinspired music and of his patriotism during both World Wars (4/1955, Table 1, column 6). In this case, nationalism was enough to ensure Ensecu's continued relevance in socialist Romania. In another article, Tudor dispelled the idea that Enescu's Piano Sonata no. 3 was a formalist construction. Even though it is "without a title," he wrote, "[it still] achieves a particularly suggestive poetic atmosphere reminiscent of the landscapes of our country and of the soul and feeling of our people." 10

In the Review's first issue, Tudor's survey of the Romanian musical scene (1/1946, Table 1, column $1)^{11}$ includes a discussion of recent musical events that, despite the waning pluralism, mentions composers Jora and Mihalovici-both of whom would shortly suffer periods of communist-instigated ostracism due

\footnotetext{
8 "L'école musicale roumaine," Revue roumaine, no. 1 (1946): 129-31. Like so many of his generation, Andricu was influenced by George Enescu and his championing of folkloric art music, so it is not surprising that this theme is given coverage.

${ }^{9}$ See Viorel Cosma, “Tudor, Andrei," in Viorel Cosma, Muzicieni din România, vol. 9 (Bucharest: Editura Muzicală, 2006), 114.

${ }^{10}$ Andrei Tudor, "George Enescu," Arts in the Rumanian People's Republic, no. 11 (1956): 67.

11 "Chronique musicale," Revue roumaine, no. 1 (1946), 132-39.
} 
to their "bourgeois leanings"-alongside Socor, Jerea and Mendelsohn-who would enjoy official patronage after the takeover. In the post-takeover period, this relatively moderate approach would give way to one which privileged socialist realism and gave prominence to programme music, music with "meaningful" texts and libretti, or music incorporating folk elements. As well as his reports on local musical events in the Review in 1946 and 1947, Tudor appears to have had an interest in writing about the musical interaction between Romania and other countries, and even after the communists began seriously to curtail Romania's western interaction, he did not suggest that the Soviet Union's cultural path was the only way forward:

the new Rumanian musical school whose membres $[$ sic $] ..$. in their majority, were brought up in the French school, had drawn from their example [Enescu, for example] and the doctrines necessary for finding a way of their own. In this way, these works could be realised which today honour the young Rumanian music. ${ }^{12}$

In "Rumanian Musicians and the Exchange of Culture," he is critical of the fact that countries in close proximity to Romania, including, notably, the Soviet Union, are not fully aware of the dimensions of Romania's musical life. ${ }^{13}$ He also criticizes Romanians' ignorance of foreign cultures, though he tactfully closes the article with a suggestion that musical interaction has been improving over the last two years. ${ }^{14}$

Such attitudes towards the Soviet Union's influence on Romanian culture would not have been tolerated six months later, when the communists had taken full control of the country. Indeed, the very next issue of the Review printed a strongly-worded article advocating Soviet-style people's democracy by Leonte Răutu, an important Party apparatchik who focussed on cultural policy during the Gheorghiu-Dej period. His 1948 article extolled the USSR as the saviour of world peace and the source of other "virtuous" cultural attributes, ${ }^{15}$ signalling that the Review's mode of expression had changed significantly by the time Răutu's essays appeared in its pages. Militant language became commonplace, but Tudor still managed to side-step "odious" political spin for a more mitigated tone in his 1955 survey article, "Rumanian Music Forges Ahead" (4/1955, Table 1, column 6). ${ }^{16}$ Following his homage to Enescu, Tudor subdivided his article into sections that, amongst other categories, include folk-based art music, oratorios, symphonic, chamber, vocal, and film music. Within each division, he took pains to highlight works that upheld the socialist realist model; programmatic scores with references to heroic figures from the past and current themes are liberally represented. The Party had rehabilitated Jora and Cuclin by the early 1950s, so Tudor was able to include them in the discussion. Naturally, composers prominent within the Composers' Union and/or the Party, including Mendelsohn, Zeno Vancea, Ion and Gheorghe Dumitrescu, Socor, Jerea and Sabin Drăgoi, were given favorable assessments. According to Tudor, these composers had been "offered the opportunity to practise their art freely," and he suggests that they "have revived the social role of art: proudly and enthusiastically they resume their true mission, that of educating the masses and contributing their part in creating the culture and new life of their people." 17

\footnotetext{
${ }^{12}$ Andrei Tudor, “The Society of Rumanian Composers," Rumanian Review, nos. 4-5 (1946): 128.

${ }^{13}$ Rumanian Review, nos. 1-2 (1947): 97.

${ }^{14}$ Ibid., 98.

${ }^{15}$ See L. Răutu, “The Road We Have Chosen,” Rumanian Review, nos. 3-4 (1947): 7-10 and L. Răutu, “After the World Congress of Intellectuals," Rumanian Review, no. 12 (October 1948): 5-9. For Răutu, see Vladimir Tismaneanu, Stalinism for All Seasons: A Political History of Romanian Communism (Berkeley: University of California Press, 2003) $267-68$.

${ }^{16}$ Rumanian Review, no. 4 (1955): 105-12.

17 Tudor, "Rumanian Music Forges Ahead," 112.
} 
While, with hindsight, one could debate whether the composers were in fact free agents, the substance of Tudor's argument would have been plausible to western eyes at the time. His justification of why some professional musicians needed to remain abroad is equally questionable: he blames the previous regime, with its failure to support its artists, for the emigration of cultural figures. ${ }^{18}$ Tudor points to increased musical opportunities within Romania (in the form of choirs, ensembles, and orchestras), and while he does not go so far as to extend the hand of friendship to these exiles, the mere reference to an émigré community in neutral terms is a good example of how the Review sought to represent Romania as a cooperative international citizen. Tudor's relaxed discussion of Romania's connection with the West was part of a growing trend in the post-Stalinist Eastern Europe to end years of cultural isolationism. ${ }^{19}$ Simultaneously, however, the authorities feared that Romanians re-entering the country might seek to undermine the regime. Of further concern was the fluidity of movement among ethnic minorities such as Germans, Hungarians, and Jews, fed by centuries of well-honed xenophobia ${ }^{20}$ and further fuelled by the land redistribution that occurred after the ratification of the Treaty of Trianon in 1920, which resulted in multiple ethnicities being "re-assigned" to Romania.

The socialist authorities heavily censored all journalistic and academic writings from the takeover period onwards. Historian Serban Papacostea recalls that the Secret Police or Securitate and its widespread informant network were constantly monitoring people accessing the State archives, and were especially interested in those who wished to view documents that might have had a negative connection to the regime. ${ }^{21}$ The Securitate kept dossiers on what people requested in the archives, and tabulated visits to the reading rooms of western embassies. Composer Mihail Andricu's show trial in 1959 was brought about in part by his persistent visits to the French embassy in Bucharest. ${ }^{22}$ Papacostea also describes the rigours of editorial scrutiny:

texts would go through long preliminary stages: the staffs of the institutes or of the specialized department within the [Romanian] Academy, the editorial boards of the specialized journals, and the editorial staffs of the publishing houses which would eventually publish the texts were to verify and vouch for the ideological purity of the writings. The ideological vigilance of staff during these compulsory stages was encouraged by the fearsome cost of any ideological "error" or "deviation." 23

Sometimes, ideological deviations within the Review were remedied by the insertion of political acceptable text anonymously. ${ }^{24}$ Anonymous entries on music and culture in general appeared occasionally

\footnotetext{
${ }^{18}$ See ibid., 109.

${ }^{19}$ See Mihail Roşianu, "International Cultural Relations of the Rumanian People's Republic," Rumanian Review, no.1 (1956): 84-89, and Ion Dunitrescu, Rumanian Musicians Visit Brussels and Paris,"Rumanian Review, no. 3 (1956): 51-54. For a general discussion of this theme, see Richard Stites, "Heaven and Hell: Soviet Propaganda Constructs the World," in ColdWar Propaganda in the 1950s, ed. Gary D. Rawnsley (London: Macmillan, 1999), 85-103.

${ }^{20}$ For a brief discussion of the regime's concerns over German-Romanians, see Johanna Granville, “Temporary Triumph in Timişoara: Unrest among Romanian Students in 1956," History: The Fournal of the Historical Association 93, no. 309 (2008): $90-$ 92.

${ }^{21}$ See Serban Papacostea, “Captive Clio: Romanian Historiography under Communist Rule,” European History Quarterly 26 (1996): 187-88.

${ }^{22}$ For a brief account of this episode, see Joel Crotty, "A Preliminary Investigation of Music, Socialist Realism, and the Romanian Experience, 1948-1959: (Re)reading, (Re)listening, and (Re)writing Music History for a Different Audience," Fournal of Musicological Research 26, nos. 2-3 (2007): 165-69. Walter L. Romanian authorities closed the British and American cultural offices in 1950 in an attempt to curb western influences. See Walter L. Hixson, Parting the Curtain: Propaganda, Culture and the Cold War, 1945-1961 (London: Macmillan, 1997), 10.

${ }^{23}$ Papacostea, 193. For an account of the strain of being a sub-editor during the Ceauşescu years, see Ben Lewis, Hammer $\mathcal{E}$

Tickle: The History of Communism Told through Communist fokes (London: Weidenfeld \& Nicolson, 2008), 4-5.

${ }^{24}$ See Kotlyar, 66ff.
} 
in the Review, and were notable for their fervent tone. One such piece, published in October 1948, used blatantly communist rhetoric to express Romania's anti-western outlook:

The press, literature, arts, cinematography and broadcast pitilessly and relentlessly denounce the imperialist warmongers and their lackeys at home and abroad, deal at them crushing blows, obliterate the influence of imperialist ideology, and scrupulously shield the culture of the Rumanian people from the influences of imperialist ideology. ${ }^{25}$

The language is certainly very different from that used in the Review two years previously. For example, in one article in 1946, Tudor expresses gratitude to both the Soviet Union and America for supplying music for performance in Romania, a classic example of fence-sitting during the period in which neither the East nor the West was politically dominant. Tudor writes,

the cultural section of the American mission is now bringing to Rumania American musical material. Owing to this fact we have had an opportunity last year [1945] to hear a symphony by Walter Piston and, ... as the material is coming in, [we] shall get acquainted with other works by the young American school. ${ }^{26}$

If Tudor was reporting international cultural exchange in 1946, then the theme in the early 1950s was that of how hard work in socialist transformation had paid off. Both George Bălan's "Upsurge of Musical Creation and Criticism in Rumanian Peoples' Republic" (8/1951) and the unsigned "Success of Rumanian Music" (9/1951, Table 1, columns 4 and 5) claim that composers were now motivated by socialist realism. But the discussion never extends to any conceptual consideration of politically-engaged music; this was the task of the Union of Composers' journal Muzica, as well as the Party's cadres.

The Composers' Union had been reorganised along Soviet lines and Muzica was full of didactic treatises in support of communist cultural policies and practices, and strong praise for socialist realist scores. ${ }^{27}$ Though these were couched as musicological discussions to a degree, it is not hard to infer that the scores under consideration were being presented as benchmarks for new Romanian compositions that would fulfil the censor's requirements. Other articles praised the use of folk music; still others were propaganda pieces designed to glorify the socialist state. Bălan reported on the music criticism section of the Union (8/1951, Table 1, column 5), proclaiming that it

will become an efficient guide for musical creation, a substantial help to composers in their effort to master socialist realism, with a view to creating an art that will be a powerful beacon on the road of the working people in our country, in their impetuous march towards Peace and Socialism. ${ }^{28}$

In effect, the Union's critical arm became the Party's ideological watchdog during the communist period, ensuring that composers did not stray too far from the Party's dictums, changeable as these were. Hence, while Muzica instructed the Union membership on how it should respond creatively to the new environment, and invigilated the prevailing ideology, the Review aimed to inform rather than guide its readership by reporting on Romania's cultural activities. Of course, a fine line separated the two, as propaganda was disseminated through both journals and no dissenting views were expressed. In his

25 "Heading for a New Culture," Rumanian Review, no. 12 (October 1948): 32.

${ }^{26}$ Andrei Tudor, "The Forthcoming Musical Season," Rumanian Review, no. 6 (October 1946): 90.

${ }^{27}$ For example, George Bălan's article on Hilda Jerea's Ode to Stalin's Law (Muzica, no. 1 [1950]: 64-67); George Breazul's article on Gheorge Dumitrescu's Tudor Vadimirescu (Muzica, no. 7 [1952]: 65-78); Ludovic Feldman's discussion of Virgil Gheorghiu's Poem for Work and Peace (Muzica, nos. 8-9 [1952]: 85-87); George Breazul's article on Nicolae Buicliu's Festive Overture (Muzica, no. 4 [1953]: 43-48).

${ }^{28}$ Bălan, "Upsurge of Musical Creation,” 36. 
seminal work Four Theories of the Press, Wilbur Schramm succinctly explains the impulse towards a unilateral journalistic trajectory as follows:

the Soviet Russians are apt to think that men should not hold different viewpoints, that compromise is a sign of weakness, that there is one right position to be found in Marxist interpretation and to be defended, propagated and enforced. To us ... [this] seems reactionary and tryrannical. To the Russians, our lack of agreement, our permissiveness towards argument, compromise, and criticism, seem anarchy or chaos. ${ }^{29}$

Matei Socor became the President of the Composers' Union in 1949, a position he held until 1954, and he was a major Party advocate and political operator within the music community. As an ardent communist he was ideal for the position; he not only guided the reform of the organisation along Soviet lines but championed socialist realism as the path to compositional relevance in the new Romania. His support for socialist realism meant that he abandoned his own more modernist compositional tendencies for a musical style that best reflected the communist aesthetic. ${ }^{30}$ In the same year that he was appointed Union President, the Review published Socor's revealing report on his reform agenda (5/1949, Table 1, column 3). The article is a series of extracts from a much larger lecture that Socor delivered to the Conference of Composers, Musical Critics, and Musicians held in Bucharest in October 1949, and revealed his determination to direct his charges towards acceptable political-cultural behaviour. He offers the reader the Stalinist model of two opposing camps, bourgeois and progressive, and gives a fait accompli argument for following Socialist principles:

one cannot claim to be a man of culture and, at the same time, maintain one's neutrality between tyranny, exploitation, war policy on one side, and the fight for a better and a fuller life of the working people, for peace, on the other. ${ }^{31}$

He suggests pragmatically that composers do not have to be card-carrying members of the Party, but their music must demonstrate the Party spirit. Socor believed that active ideological engagement was to be carried out "through discussions by man to man" as well as "visits to construction-sites and factories [that] marked the beginning of a closer contact with workers in production." ${ }^{32}$ Predictably, he condemned cosmopolitan traits that headed,

towards ever more abstract melody, towards the adoption of an ever more dissonant harmony_-sometimes even totally lacking tonality_and especially an infatuation for exotic, mythologic and other themes having no connection whatever with our people.

The Acteons, Armides, Agamemnons, Hecubes, Marsyas, Oedips, are peopling Rumanian music from which Doja, Horia, Tudor, Bălcescu, and all the revolutionary heroes of the Rumanian people are totally absent. ${ }^{33}$

The Stalinist campaign against cosmopolitanism, which lasted from 1949 to 1953, is strongly echoed here, reflecting the communist propagandist's notion of one correct position and the Party's need to reiterate its messages. ${ }^{34}$ To make sure that composers maintained continuous commitment to the cause of

\footnotetext{
${ }^{29}$ Wilbur Schramm, “The Soviet Communist Theory of the Press,” in Fred S. Siebert, Theodore Peterson, and Walter Schramm, Four Theories of the Press (Urbana: University of Illinois Press, 1963), 107.

${ }^{30}$ Grigore Constantinescu, Matei Socor (Bucharest: Editura Muzicală, 1983).

${ }^{31}$ Matei Socor, "Musical Problems in the Rumanian People's Republic," Rumanian Review, no. 5 (1949): 36.

${ }^{32}$ Ibid., 46.

${ }^{33}$ Ibid., 40.

${ }^{34}$ A. Kotlyar, Newspapers in the USSR: Recollections and Observations of a Soviet fournalist, trans. Fred Holling [mimeographed series no. 71] (New York: New York Research Program of the USSR, 1955), 62.
} 
socialist realism, Socor advocated criticism and self-criticism within the Union's music circles. ${ }^{35}$ Buoyed by the strongarm tactics of the Soviet Union's cultural policymaker Andrei Zhdanov in the previous year-which had witnessed composer purges and re-affirmations of socialist realism-Socor targeted Romanian composers who he believed were not reaching their socialist potential. Mihail Jora and Paul Constantinescu "are still holding [to] their former decadent and obscurantist positions and composing, even today, a music peopled by ghosts haunting boyard mansions and mystic oratorios." ${ }^{\text {6 }}$ Socor criticized Constantin Silvestri's output for its "strong formalist accent," ${ }^{37}$ and offered muted negative criticism of Andricu's music with its "French impressionistic and naturalistic influences." Socor balanced this with praise for Andricu's folk music-inspired scores, suggesting that "the content ... could acquire a socialist sense" ${ }^{38}$ and, later in the article, cited Andricu's Cantata to Stalin as a successful demonstration of Romania's new epoch. ${ }^{39}$

As if to make the critical commentary democratic, Socor also negatively targeted composers with strong connections with socialist realism such as Jerea, Mendelsohn, and Vancea, due to the "remains of old formalist conceptions" located in their music. These committed composers, suggests Socor, "struggle to obtain the method of Socialist Realism," a comment that perhaps says more about the concept's brittle aesthetic, whose meaning composers "struggled" to pinpoint accurately.

Articles attempting an articulation of what constituted good socialistic elements also strained to avoid convolution, such as this anonymous article from 1951:

the best creations of the new music would have been impossible had not the composers made use of new musical intonations as main means of expression. Those new intonations are deeply rooted in the masses and in the reality of our times, when our people are building Socialism. Typical in this respect are the popular revolutionary songs and the rich treasure of the folklore, alive in the people and enriched by them with new intonations and interpretations. ${ }^{40}$

Scores with folk music inflections or politically-inspired content appear to have had the correct "musical intonations" and as such fulfilled the rhetorical requirement that they be "national in form and socialist in content." Folk music was a cornerstone of socialist realism through which the communist regime sought subtly to enhance its claim as the legitimate group to lead the nation. ${ }^{41}$ By championing folk music the Party was able to promote the image of itself as having "a natural identification" with "the people," since a party that supports its own musical heritage cannot be charged with being out of touch with "the people," "discursively reconstituted as a union of 'the workers' and 'the working peasantry'."

In mid-1947, just before the communists had gained total control, musicologist Harry Brauner published his article "Individual and Collective Creation in Rumanian Popular Music," in which he argues that folk music should be considered as being in "continual transformation," due in part to its oral tradition. ${ }^{42}$ This meant that folk music was not only traditional but a new musical life force and thus ideal for a society in transformation. The Party commodified folk culture, and practitioners of so-called "high

\footnotetext{
${ }^{35}$ Socor, 49.

${ }^{36}$ Ibid., 47.

${ }^{37}$ Ibid., 47.

${ }^{38}$ Ibid., 40 .

${ }^{39}$ Ibid., 45.

40 "Success of Rumanian Music," Rumanian Review, no. 9 (1951): 217.

${ }^{41}$ For a discussion of the importance of consent to the regime, and for quotations, see Kevin Adamson, "Discourses of Violence and the Ideological Strategies of the Romanian Communist Party, 1944-1953," East European Politics and Societies 21, no. 4 (2007): 561.

${ }^{42}$ Rumanian Review, nos 11-12 (1947): 75.
} 
art" could appropriate folk flavourings for their works, while peasant performers were regulated into groups to act out staged versions of village life. But after the colourful costumes had been put away and the decorative displays of flowers and bountiful harvests disposed of, peasants were encouraged to reject their village ways and embrace agricultural collectivization as a means of socialist liberation. A good example of the celebration of "improvement" is found in the Review in 1953, when an anonymous writer attests that Ion Cudalbu, a "young shepherd" with an impressive flute technique, was able to benefit from the reformed music education system, and "within a short time, this gifted youth acquired the technique of the clarinet, becoming a proper virtuoso." ${ }^{43}$

In socialist Romania "virtuosity" was not intended to support cultural experimentalism but rather to underpin the "duties and obligations that counter-balanced the new 'right' and freedoms that were offered." ${ }^{44}$ The Party demanded a disciplined composer coterie, and this is clearly expressed in George Bălan's 1951 music survey, "Upsurge of Musical Creation and Criticism in Rumanian People's Republic" (8/1951, Table 1, column 5). Bălan supported the regime, but as a vigorous, youthful conservatorium student rather than a mature politician. His article, a celebratory piece on the first anniversary of the Composers' Union, demonstrated that the organization was in step with the regime, giving more space to a defence of socialism than to a discourse on the music. Overall, Bălan is concerned with the "struggle" to win "peace and progress." ${ }^{45}$ He establishes the East-West divide with phrases such as "the decaying fruit of the bourgeois order" and the "triumph of Socialism"; buzz words surrounding "struggle," "fight," "peace," "formalist," and "cosmopolitan remnants" appear throughout the short, repetitive essay.

While he included the usual list of favored composers such as Mendelsohn, Jerea, Vancea, and Klepper, it is surprising that Bălan made no mention of Socor. On the other hand, Bălan maintained the Party's disenfranchisement of Jora and Cuclin by avoiding any discussion of their music. Jora and Cuclin suffered short-term ostracism for their failure to throw off "bourgeois intellectualism" and the taint of old politics; Cuclin also had to endure a period of time in a labour camp. It was only in the cultural thaw of the post-Stalinist era and after the end of Socor's Union presidency that these two composers, amongst others, were able to rejoin the musical community, and re-appear in its discourses without negative reference.

\section{Conclusion}

The articles surveyed reveal much through the absence of those prominent members of the composer cohort who failed for a time to meet the requirements of the new system. While this lacuna enhances the articles' usefulness, the list of programmatic scores in praise of peace, Stalin, or comradeheroes discussed in the Review, also has direct interest for music historians, inasmuch as these cultural presentations mirror the contemporary political landscape. For a western reader, the mere mention of symphonies and string quartets suggests abstract individualism as quickly as a cantata praising the State reconfirms a more collective approach. By blurring the line between individualism and collectivism in promoting Romanian music abroad, the authorities could perhaps conceal the extent of cultural (and political) rupture that was occurring within the country.

\footnotetext{
43 “An Orchestra of Young Musicians," Rumanian Review, no. 1 (1953): 161.

${ }^{44}$ E. A. Rees, "The Sovietization of Eastern Europe," in The Sovietization of Eastern Europe: New Perspectives on the Postwar Period, ed. Balázs Apor, Péter Apor, and E.A. Rees (Washington: New Academia, 2008), 7.

${ }^{45}$ Rumanian Review, no. 8 (1951): 33.
} 
And what of the music itself? Marina Frolova-Walker has argued that the communists' obsession with a score's accessibility meant that much of the music produced was monochrome in hue-in other words, that judgement of a work's creativity rested on its melodic interest and its successful prosody, if a text were used, rather than on any deeper level of technical competence such as use of counterpoint or chromaticism. She suggests that socialist realist works were thus "uniformly tedious," and goes on to say that "a composer's success or failure was decided by the organs of the State, not by the public." " She also notes that, in the Soviet Union at least, such music rarely received more than one performance, which for her is validation of her view of the music's limitations.

I do not aim to judge whether or not the pieces listed in these articles manifest the creative shortcomings that would place them within Frolova-Walker's critique of socialist realist regimentation. However, whether they were praising Stalin, advocating peace, supporting current large-scale projects such as the Danube-Black Sea canal, or darkly critiquing the old regime, ${ }^{47}$ these scores offer a snapshot of Romanian compositional activity at the time. From an historical perspective, Table 1 demonstrates the diversity of themes with which composers were able to generate creative works, and it is this variety that allows us to contextualize the "collective" that was the marriage (whether of convenience or otherwise) of composers and the state in this transitional period.

\footnotetext{
${ }^{46}$ Marina Frolova-Walker, "Stalin and the Art of Boredom," in Twentieth-Century Music 1, no. 1 (2004): $103,105$.

${ }^{47}$ For example, Leon Klepper's symphonic poem From the Danube to the Sea (1949); Alfred Mendelsohn's symphonic poem The Fall of Doftana (1949); Sabin Drăgoi's symphonic poem In Memory of a Woman-Comrade Who Fell in the Underground Struggle (1951). Doftana was the prison in which many pre-takeover political prisoners were held.
} 


\begin{abstract}
This essay examines a selection of articles about music that were published in the Romanian Review between 1946 and 1955, a time of political transition and cultural realignment. The Review, a monthly literary magazine published in Bucharest in several languages, targeted the surviving intelligentsia within the country and an interested intellectual readership beyond its borders. Articles analysed reflect the Party's requirement that the journal should demonstrate Romania's loyalty to the emerging socialist system, and publicise that, in reorganising the country's cultural life, the Party had not necessarily abandoned Romania's cultural traditions. The study investigates how music was utilised as a tool of governance, how authors shaped their discussion in relation to the prevailing, and sometimes shifting, ideology, and what can be inferred about the supported and marginalized composers in this period. A table of named composers and compositions is included.
\end{abstract}


Table 1. A list of the composers mentioned in a selection of articles from the Rumanian Review between 1946 and 1956. The authors were not always specific or accurate when referring to the music - possibly the data was lost in translation. As a consequence, some of the information that was too vague did not find its way on to this table. $\sqrt{ }=$ composer mentioned without reference to scores; $\mathrm{X}=$ unfavourable comments on the composer; $-=$ no mention of the composer. (Continued on following pages.)

\begin{tabular}{|c|c|c|c|c|c|c|}
\hline Composer name & $\begin{array}{c}\text { Tudor } \\
R R: 1 / 1946 \\
\end{array}$ & $\begin{array}{c}\text { Tudor } \\
R R: 1 \& 2 / 1947 \\
\end{array}$ & $\begin{array}{c}\text { Socor } \\
R R: 5 / 1949 \\
\end{array}$ & $\begin{array}{c}\text { Anon } \\
R R: \text { 9/1951 }\end{array}$ & $\begin{array}{c}\text { Bălan } \\
R R: \text { 8/1951 }\end{array}$ & $\begin{array}{c}\text { Tudor } \\
\text { RR: 4/1955 }\end{array}$ \\
\hline $\begin{array}{l}\text { Alessandrescu, } \\
\text { Alfred (1893-1959) }\end{array}$ & $\sqrt{ }$ & - & - & - & - & - \\
\hline $\begin{array}{l}\text { Alexandrescu, Dragoş } \\
\text { (b.1924) }\end{array}$ & $\sqrt{ }$ & - & - & - & $\sqrt{ }$ & - \\
\hline $\begin{array}{l}\text { Albin, Anatol } \\
(1903-1974)\end{array}$ & - & - & $\sqrt{ }$ & - & - & - \\
\hline $\begin{array}{l}\text { Andricu, Mihail } \\
(1894-1974)\end{array}$ & $\sqrt{ }$ & $\sqrt{ }$ & $\begin{array}{c}\text { - Symphony no. } 2 \\
\text { - Cantata to Stalin } \\
\& \\
\mathrm{X}\end{array}$ & $\begin{array}{l}\text {-Symphony no. } 2 \\
\text {-Symphony no. } 3\end{array}$ & $\begin{array}{l}\text {-Symphony no. } 2 \\
\text {-Symphony no. } 3\end{array}$ & $\begin{array}{l}\text { - Symphony no. } 2 \\
\text { - Symphony no. } 3 \\
\text { - Symphony no. } 4 \\
\text { - Sinfonietta no. } 3 \\
\text { - Sinfonietta no. } 4 \\
\text { - Rumanian-Soviet } \\
\text { Friendship Overture }\end{array}$ \\
\hline $\begin{array}{l}\text { Barbu, Filaret } \\
(1903-1984)\end{array}$ & - & - & - & - & - & - Ana Lugojana \\
\hline $\begin{array}{l}\text { Bentoiu, Pascal } \\
\text { (b. 1927) }\end{array}$ & - & - & - & - & - & $\sqrt{ }$ \\
\hline $\begin{array}{l}\text { Bugeanu, Constantin } \\
(1916)\end{array}$ & $\sqrt{ }$ & $\sqrt{ }$ & - & - & - & - \\
\hline $\begin{array}{l}\text { Buicliu, Nicolae } \\
(1906-1974)\end{array}$ & $\sqrt{ }$ & - & $\sqrt{ }$ & -Symphony no. 2 & -Symphony no. 2 & -Symphony no. 2 \\
\hline $\begin{array}{l}\text { Brăiloiu, Constantin } \\
(1893-1958)\end{array}$ & $\sqrt{ }$ & $\sqrt{ }$ & - & - & - & - \\
\hline $\begin{array}{l}\text { Bratu, Teodor } \\
\text { (b. 1922) }\end{array}$ & - & - & - & - & - & $\sqrt{ }$ \\
\hline $\begin{array}{l}\text { Chirescu, Ion } \\
(1889-1980) \\
\end{array}$ & - & - & $\sqrt{ }$ & $\begin{array}{c}\cdot \text { Hymn of the Peace } \\
\text { Partisans }\end{array}$ & $\sqrt{ }$ & $\sqrt{ }$ \\
\hline $\begin{array}{l}\text { Chiriac, Mircea } \\
(1919-1994)\end{array}$ & - & - & $\sqrt{ }$ & $\sqrt{ }$ & - & $\sqrt{ }$ \\
\hline $\begin{array}{l}\text { Ciortea, Tudor } \\
(1903-1982)\end{array}$ & - & - & - & - & - & $\sqrt{ }$ \\
\hline
\end{tabular}




\begin{tabular}{|c|c|c|c|c|c|c|}
\hline Composer name & $\begin{array}{c}\text { Tudor } \\
\text { RR: 1/1946 }\end{array}$ & $\begin{array}{c}\text { Tudor } \\
R R: 1 \& 2 / 1947\end{array}$ & $\begin{array}{c}\text { Socor } \\
R R: 5 / 1949 \\
\end{array}$ & $\begin{array}{c}\text { Anon } \\
R R: \text { 9/1951 }\end{array}$ & $\begin{array}{c}\text { Bălan } \\
R R: \text { 8/1951 }\end{array}$ & $\begin{array}{c}\text { Tudor } \\
\text { RR: 4/1955 }\end{array}$ \\
\hline $\begin{array}{l}\text { Constant, Marius } \\
(1925-2004)\end{array}$ & $\sqrt{ }$ & - & - & - & - & - \\
\hline $\begin{array}{l}\text { Constantinescu, Paul } \\
(1909-1963)\end{array}$ & - & $\sqrt{ }$ & $\mathrm{X}$ & - & •Rhapsody no. 2 & $\begin{array}{c}\text { • Brâul } \\
\bullet \text { Olteneasca } \\
\text { • Piano Concerto } \\
\text { • Four Madrigals } \\
\text { - A Stormy Night } \\
\text { - Panǎ Lesnea Rusalim } \\
\text {-The Danube Delta }\end{array}$ \\
\hline $\begin{array}{l}\text { Cosma, Edgar } \\
\text { (b. 1925) }\end{array}$ & - & - & - & - & - & -Piano Trio \\
\hline $\begin{array}{l}\text { Cucu, Gheorghe } \\
(1882-1932)\end{array}$ & - & - & $\sqrt{ }$ & $\sqrt{ }$ & - & $\sqrt{ }$ \\
\hline $\begin{array}{l}\text { Cuclin, Dumitrie } \\
(1885-1978)\end{array}$ & $\sqrt{ }$ & $\sqrt{ }$ & - & - & - & $\sqrt{ }$ \\
\hline $\begin{array}{l}\text { Danga, Radu } \\
(1905-1959)\end{array}$ & - & - & $\sqrt{ }$ & - & - & - \\
\hline $\begin{array}{l}\text { Dendrino, Gherase } \\
(1901-1973)\end{array}$ & - & - & - & - & - & - Let me sing \\
\hline $\begin{array}{l}\text { Dima, Gheorghe } \\
(1847-1925)\end{array}$ & - & - & - & $\sqrt{ }$ & - & - \\
\hline $\begin{array}{l}\text { Doboş, Viorel } \\
(1917-1985) \\
\end{array}$ & - & - & $\sqrt{ }$ & - & - & - Moldavian Uplands \\
\hline $\begin{array}{l}\text { Drănga, Radu } \\
(1909-198 ?)\end{array}$ & - & - & $\sqrt{ }$ & - & - & - \\
\hline $\begin{array}{l}\text { Drăgoi, Sabin } \\
(1908-1968)\end{array}$ & $\sqrt{ }$ & - & $\sqrt{ }$ & $\begin{array}{c}\text { - Six Scenes from the } \\
\text { Life of Working } \\
\text { Peasants }\end{array}$ & - & $\begin{array}{l}\text { - In Memory of a } \\
\text { Woman-Comrade } \\
\text { Who Fell in the } \\
\text { Underground Struggle } \\
\text { - Mitrea Cocor }\end{array}$ \\
\hline
\end{tabular}




\begin{tabular}{|c|c|c|c|c|c|c|}
\hline Composer name & $\begin{array}{c}\text { Tudor } \\
\text { RR: 1/1946 }\end{array}$ & $\begin{array}{c}\text { Tudor } \\
R R: 1 \& 2 / 1947 \\
\end{array}$ & $\begin{array}{c}\text { Socor } \\
R R: 5 / 1949\end{array}$ & $\begin{array}{c}\text { Anon } \\
R R: \text { 9/1951 }\end{array}$ & $\begin{array}{c}\text { Bălan } \\
R R: \text { 8/1951 }\end{array}$ & $\begin{array}{c}\text { Tudor } \\
R R: 4 / 1955\end{array}$ \\
\hline $\begin{array}{l}\text { Dumitrescu, Gheorghe } \\
\text { (1914-1996) }\end{array}$ & - & - & $\sqrt{ }$ & - Tudor Vladimirescu & - & $\begin{array}{l}\text { - Tudor Vladimirescu } \\
\text { - Prince John the Terrible }\end{array}$ \\
\hline $\begin{array}{l}\text { Dumitrescu, Ion } \\
(1913-1994)\end{array}$ & $\sqrt{ }$ & - & $\sqrt{ }$ & - & $\sqrt{ }$ & $\begin{array}{c}\text { - Symphony no. } 1 \\
\text { - Suite no. } 3 \\
\text { - The Bugler's } \\
\text { Grandchildren } \\
\text { (film score) } \\
\text { - Sunrise (film score) }\end{array}$ \\
\hline $\begin{array}{l}\text { Eisikovits, Max } \\
(1908-1983)\end{array}$ & - & - & -Vultures of Vengeance & $\sqrt{ }$ & -Vultures of Vengeance & - The Goat's Tale \\
\hline $\begin{array}{l}\text { Enescu, George } \\
(1881-1955)\end{array}$ & $\sqrt{ }$ & - & $\begin{array}{c}\cdot \text { Rumanian Rhapsodies } \\
\text { [1\&2] }\end{array}$ & $\sqrt{ }$ & - & $\sqrt{ }$ \\
\hline $\begin{array}{l}\text { Feldman, Ludovic } \\
(1893-1987)\end{array}$ & - & - & - Suite no. 2 & - & $\sqrt{ }$ & $\begin{array}{c}\text { - Concertante Fantasy for } \\
\text { cello and orchestra } \\
\text { - Concertante Poem for } \\
\text { violin and orchestra } \\
\text { - Flute Concerto } \\
\text { - Wind Trio }\end{array}$ \\
\hline $\begin{array}{l}\text { Gheciu, Diamandi } \\
(1892-1982)\end{array}$ & - & - & $\sqrt{ }$ & - & - & $\sqrt{ }$ \\
\hline $\begin{array}{l}\text { Gheorghiu, Virgil } \\
(1905-1977)\end{array}$ & - & - & - & - & - & $\begin{array}{c}\cdot \text { Piano Concerto } \\
\cdot \text { Piano Trio } \\
\end{array}$ \\
\hline $\begin{array}{l}\text { Giroveanu, Aurel } \\
\text { (b.1916) }\end{array}$ & - & - & $\sqrt{ }$ & - This Is My Country & $\sqrt{ }$ & - \\
\hline $\begin{array}{l}\text { Golestan, Stan } \\
(1875-1956) \\
\end{array}$ & $\sqrt{ }$ & $\sqrt{ }$ & - & - & - & $\sqrt{ }$ \\
\hline $\begin{array}{l}\text { Grigoriu, Theodor } \\
\text { (b. 1926) }\end{array}$ & - & - & - & $\begin{array}{c}\text { - Cantata for the } 23^{\text {rd }} \\
\text { of August (Liberation } \\
\text { Day) }\end{array}$ & - & $\sqrt{ }$ \\
\hline $\begin{array}{l}\text { Iancu, Mişu } \\
(1900-1994)\end{array}$ & - & - & $\sqrt{ }$ & - & - & - \\
\hline
\end{tabular}




\begin{tabular}{|c|c|c|c|c|c|c|}
\hline Composer name & $\begin{array}{c}\text { Tudor } \\
R R: 1 / 1946\end{array}$ & $\begin{array}{c}\text { Tudor } \\
\text { RR: } 1 \text { \& 2/ } 1947\end{array}$ & $\begin{array}{c}\text { Socor } \\
R R: 5 / 1949 \\
\end{array}$ & $\begin{array}{c}\text { Anon } \\
\text { RR: 9/1951 }\end{array}$ & $\begin{array}{c}\text { Bălan } \\
R R: \text { 8/1951 }\end{array}$ & $\begin{array}{c}\text { Tudor } \\
\text { RR: 4/1955 }\end{array}$ \\
\hline $\begin{array}{l}\text { Ionescu, Emanuel } \\
\text { (1912-c.1995) }\end{array}$ & - & - & $\sqrt{ }$ & - & - & - \\
\hline $\begin{array}{l}\text { Jelescu, Paul } \\
(1901-1989)\end{array}$ & - & - & - & - & - & $\sqrt{ }$ \\
\hline $\begin{array}{l}\text { Jerea, Hilda } \\
(1916-1980)\end{array}$ & $\sqrt{ }$ & $\sqrt{ }$ & $\begin{array}{c}- \text { Ode to Stalin's Law } \\
\text {-Piano Suite } \\
\text { - Rumanian Dances } \\
\& \\
\text { X }\end{array}$ & $\begin{array}{c}- \text { Ode to } \\
\text { Stalin's law }\end{array}$ & $\sqrt{ }$ & $\begin{array}{c}\text { - Under the Sun } \\
\text { of Peace } \\
\text { - Mihu and Ioana }\end{array}$ \\
\hline $\begin{array}{l}\text { Jora, Mihail } \\
(1891-1971)\end{array}$ & $\sqrt{ }$ & $\sqrt{ }$ & $\mathrm{X}$ & - & - & $\begin{array}{c}\text {-When the Grapes Are } \\
\text { Ripe }\end{array}$ \\
\hline $\begin{array}{l}\text { Kirculescu, Nicolae } \\
(1903-1985)\end{array}$ & - & - & - Four Concert Studies & - & - & $\begin{array}{c}- \text { There Was Never a } \\
\text { Finer Wedding }\end{array}$ \\
\hline $\begin{array}{l}\text { Kiriac, Dumitru } \\
(1868-1928)\end{array}$ & - & - & - & - & - & $\sqrt{ }$ \\
\hline $\begin{array}{l}\text { Klein, George } \\
\text { (b.1921) }\end{array}$ & - & - & - & $\begin{array}{l}\text { - Cantata for } \\
\text { May Day }\end{array}$ & $\begin{array}{l}\cdot \text { Song of a } \\
\text { New Dawn }\end{array}$ & $\sqrt{ }$ \\
\hline $\begin{array}{l}\text { Klepper, Leon } \\
(1900-1983 ?)\end{array}$ & - & - & - Little Suite & $\begin{array}{c}\text { - From the Danube to } \\
\text { the Sea }\end{array}$ & $\begin{array}{c}\text { - From the Danube to } \\
\text { the Sea }\end{array}$ & $\begin{array}{c}\text { - Four Symphonic Dances } \\
\text { - From the Danube } \\
\text { to the Sea } \\
\text { - Ode to Bălcescu } \\
\text { - Piano Concerto }\end{array}$ \\
\hline $\begin{array}{l}\text { Lazăr, Filip } \\
(1894-1936)\end{array}$ & $\sqrt{ }$ & $\sqrt{ }$ & - & - & - & - \\
\hline Lindenberg, Eduard & $\sqrt{ }$ & - & - & - & - & - \\
\hline $\begin{array}{l}\text { Márkos, Albert } \\
(1914-1981)\end{array}$ & - & - & - & - & - & $\sqrt{ }$ \\
\hline
\end{tabular}




\begin{tabular}{|c|c|c|c|c|c|c|}
\hline Composer name & $\begin{array}{c}\text { Tudor } \\
R R: 1 / 1946 \\
\end{array}$ & $\begin{array}{c}\text { Tudor } \\
R R: 1 \& 2 / 1947 \\
\end{array}$ & $\begin{array}{c}\text { Socor } \\
R R: 5 / 1949 \\
\end{array}$ & $\begin{array}{c}\text { Anon } \\
R R: 9 / 1951\end{array}$ & $\begin{array}{c}\text { Bălan } \\
R R: 8 / 1951\end{array}$ & $\begin{array}{c}\text { Tudor } \\
R R: 4 / 1955\end{array}$ \\
\hline $\begin{array}{l}\text { Mendelsohn, Alfred } \\
(1910-1966)\end{array}$ & $\sqrt{ }$ & $\sqrt{ }$ & $\begin{array}{c}\bullet \text { Harap Alb } \\
\text {-Nine Short Pieces for } \\
\text { Middle Degree } \\
\bullet \text { Folk Dances } \\
\text { and Plays } \\
\& \\
\text { X }\end{array}$ & $\begin{array}{l}\text { - The White Moor } \\
\text {-Symphony no. } 3 \\
\text { "Reconstruction" } \\
\text { - Symphony no. } 4 \\
\text { "Peace Appeal" } \\
\text { - The Destruction of } \\
\text { Doftana }\end{array}$ & $\begin{array}{l}\text {-Symphony no. } 3 \\
\text { "Reconstruction" }\end{array}$ & $\begin{array}{l}\text { - Cantata of Bucharest } \\
\text { - Symphony no. } 4 \\
\text { "Peace Appeal" } \\
\text { - Symphony no. } 5 \\
\text { - The Destruction } \\
\text { of Doftana } \\
\text { - Flowers for Nikos } \\
\text { Beloyannis } \\
\text {-Piano Quintet } \\
\text {-Harap Alb }\end{array}$ \\
\hline $\begin{array}{l}\text { Mihalovici, Marcel } \\
(1898-1985)\end{array}$ & $\sqrt{ }$ & - & - & - & - & - \\
\hline $\begin{array}{l}\text { Musicescu, Gavriil } \\
(1847-1903)\end{array}$ & - & - & - & - & - & $\sqrt{ }$ \\
\hline $\begin{array}{l}\text { Natra, Sergiu } \\
\text { (b.1924) }\end{array}$ & - & - & $\begin{array}{l}\text { - Cantata on the Theme } \\
\text { of a March } \\
\text { - New Fields on the } \\
\text { Pruth Floodplains } \\
\text { - Suite for Children }\end{array}$ & $\begin{array}{l}\text { - New Fields on the } \\
\text { Pruth Floodplains }\end{array}$ & $\begin{array}{l}\text { - New Fields on the } \\
\text { Pruth Floodplains }\end{array}$ & $\begin{array}{l}\text { - Symphony no. } 1 \\
\text { - New Fields on the } \\
\text { Pruth Floodplains }\end{array}$ \\
\hline $\begin{array}{l}\text { Negrea, Marţian } \\
(1893-1973)\end{array}$ & $\sqrt{ }$ & $\sqrt{ }$ & - Rumanian Rhapsody & - & - & $\begin{array}{c}\text { - Tarantella } \\
\text {-In the Apuseni } \\
\text { Mountains }\end{array}$ \\
\hline $\begin{array}{l}\text { Nottara, Constantin } \\
(1890-1951)\end{array}$ & - & $\sqrt{ }$ & - & - & - & - \\
\hline $\begin{array}{l}\text { Otescu, Ion } \\
(1888-1940)\end{array}$ & $\sqrt{ }$ & - & - & - & - & - \\
\hline $\begin{array}{l}\text { Palade, Constantin } \\
(1915-1974)\end{array}$ & - & - & $\sqrt{ }$ & - & - & $\begin{array}{l}\text { - The Ballad of } \\
\text { Gheorghe Doja }\end{array}$ \\
\hline $\begin{array}{l}\text { Paladi, Radu } \\
\text { (b.1927) }\end{array}$ & - & - & $\sqrt{ }$ & - & - & $\sqrt{ }$ \\
\hline
\end{tabular}




\begin{tabular}{|c|c|c|c|c|c|c|}
\hline Composer name & $\begin{array}{c}\text { Tudor } \\
\text { RR: 1/1946 }\end{array}$ & $\begin{array}{c}\text { Tudor } \\
R R: 1 \& 2 / 1947\end{array}$ & $\begin{array}{c}\text { Socor } \\
R R: 5 / 1949\end{array}$ & $\begin{array}{c}\text { Anon } \\
R R: \text { 9/1951 }\end{array}$ & $\begin{array}{c}\text { Bălan } \\
R R: \text { 8/1951 }\end{array}$ & $\begin{array}{c}\text { Tudor } \\
R R: 4 / 1955\end{array}$ \\
\hline $\begin{array}{l}\text { Perlea, Ionel } \\
(1900-1970)\end{array}$ & - & $\sqrt{ }$ & - & - & - & - \\
\hline $\begin{array}{l}\text { Popovici, Doru } \\
\text { (b. 1932) }\end{array}$ & - & - & - & - & - & $\sqrt{ }$ \\
\hline $\begin{array}{l}\text { Popovici, Vasile } \\
(1900-1973)\end{array}$ & - & - & $\sqrt{ }$ & $\sqrt{ }$ & $\sqrt{ }$ & - \\
\hline $\begin{array}{l}\text { Porumbescu, Ciprian } \\
(1853-1883)\end{array}$ & - & - & $\sqrt{ }$ & - & - & - \\
\hline $\begin{array}{l}\text { Profeta, Laurenţiu } \\
\text { (b.1925) }\end{array}$ & - & - & •In Our Mountains & - & $\begin{array}{c}\text { - Song for the } \\
\text { Defence of Peace }\end{array}$ & - In Our Mountains \\
\hline $\begin{array}{l}\text { Rogalski, Theodor } \\
(1901-1954)\end{array}$ & $\sqrt{ }$ & $\sqrt{ }$ & - & - & - & $\begin{array}{c}- \text { Three Symphonic } \\
\text { Dances }\end{array}$ \\
\hline $\begin{array}{l}\text { Roman, Elly } \\
(1905-1996)\end{array}$ & - & - & - Gypsy Rhapsody & - & - & - \\
\hline $\begin{array}{l}\text { Silvestri, Constantin } \\
(1913-1969)\end{array}$ & - & $\sqrt{ }$ & $\mathrm{X}$ & - & - & $\begin{array}{c}\text {-Three Rumanian } \\
\text { Dances }\end{array}$ \\
\hline $\begin{array}{l}\text { Socor, Matei } \\
(1908-1980)\end{array}$ & $\sqrt{ }$ & $\sqrt{ }$ & - & - Romance & - & -Mother \\
\hline $\begin{array}{l}\text { Stoia, Achim } \\
(1910-1973)\end{array}$ & - & - & $\sqrt{ }$ & - & $\begin{array}{c}\text { - Three Dances from } \\
\text { Transylvania } \\
\end{array}$ & $\sqrt{ }$ \\
\hline $\begin{array}{l}\text { Toduţǎ, Sigismund } \\
(1908-1991)\end{array}$ & - & - & - & - & - & Symphony no. 1 \\
\hline $\begin{array}{l}\text { Vancea, Zeno } \\
(1900-1991)\end{array}$ & - & - & $\begin{array}{c}\cdot \text { Sinfonietta [no. 1] } \\
\& \\
\text { X } \\
\end{array}$ & - & $\begin{array}{c}\text { - Banat Rhapsody } \\
\text { [no. 2] }\end{array}$ & $\begin{array}{c}\text { - Sinfonietta [no.1] } \\
\text {-Banat Rhapsody } \\
\text { no. } 2\end{array}$ \\
\hline $\begin{array}{l}\text { Varga, Ovidiu } \\
(1913-1993)\end{array}$ & - & - & - & - & - & - Illegal Scînteia \\
\hline $\begin{array}{l}\text { Vescan, Mauriciu } \\
\text { (b.1916) }\end{array}$ & - & - & $\sqrt{ }$ & $\sqrt{ }$ & - & $\sqrt{ }$ \\
\hline $\begin{array}{l}\text { Vidu, Ion } \\
(1863-1931) \\
\end{array}$ & - & - & $\sqrt{ }$ & $\sqrt{ }$ & - & $\sqrt{ }$ \\
\hline $\begin{array}{l}\text { Vieru, Anatol } \\
(1926-1998)\end{array}$ & - & - & - & $\begin{array}{c}\text { - Illie Pintilie's } \\
\text { Blackbird } \\
\text { - Cantata for Stalin } \\
\end{array}$ & $\begin{array}{c}\text { - Illie Pintilie's } \\
\text { Blackbird } \\
\text { - Cantata for Stalin } \\
\end{array}$ & $\begin{array}{c}\text {-Ilie Pintilie's } \\
\text { Blackbird } \\
\text { •Violin Concerto } \\
\end{array}$ \\
\hline Wechsler, Isidor & - & - & - & - & - & - Violin Concerto \\
\hline
\end{tabular}

